\title{
RETROPERITONEAL PARAGANGLIOMA: A CASE REPORT
}

\author{
Swapnil Walke1, Rohit Patil2, Shriram Nawade3, Vinayak Sawardekar4, Vijay Krishna Joglekar 5
}

${ }_{11}^{\text {st }}$ Year Junior Resident, Department of Medicine, Grant Medical College \& Sir J. J. Group of Hospitals, Mumbai.

$2^{2}$ nd Year Junior Resident, Department of Medicine, Grant Medical College \& Sir J. J. Group of Hospitals, Mumbai.

$32^{\text {nd }}$ Year Junior Resident, Department of Medicine, Grant Medical College \& Sir J. J. Group of Hospitals, Mumbai.

${ }^{4}$ Assistant Professor, Department of Medicine, Grant Medical College \& Sir J. J. Group of Hospitals, Mumbai.

5 Professor \& HOD, Department of Medicine, Grant Medical College \& Sir J. J. Group of Hospitals, Mumbai.

\section{ABSTRACT}

Paraganglioma is an extra-adrenal tumour of the autonomic nervous system. Definitive diagnosis of paraganglioma is usually done with histologic examination. Surgical removal is the treatment of choice for symptomatic paraganglioma. We report a case of functional retroperitoneal paraganglioma in a 35-year-old patient who presented with symptoms of intermittent headache, palpitation and sweating.

\section{KEYWORDS}

Retroperitoneal, Paraganglioma.

HOW TO CITE THIS ARTICLE: Walke S, Patil R, Nawade S, et al. Retroperitoneal paraganglioma: a case report. J. Evolution Med. Dent. Sci. 2016;5(63):4497-4499, DOI: 10.14260/jemds/2016/1025

\section{INTRODUCTION}

Pheochromocytomas and paragangliomas are rare tumours, which cause excessive catecholamine release. ${ }^{1}$ Paraganglioma is an extra-adrenal tumour of the autonomic nervous system, which may be seen in head, neck, chest or abdominal region. ${ }^{2}$ Paragangliomas are less common than pheochromocytoma. ${ }^{3}$ Abdominal region is the most common location of paraganglioma. ${ }^{3}$ When present in the abdominal cavity, paraganglioma may present as retroperitoneal mass and may present with symptoms related to organs in the retroperitoneal region. ${ }^{2}$ Paragangliomas can be functional or non-functional. Functional paragangliomas secrete catecholamines such as norepinephrine and normetanephrine. Non-functioning paragangliomas usually do not produce any symptom; however, when enlarged in size, pain may be the presenting symptoms due to compression of surrounding organ. ${ }^{4}$ We report a rare case of retroperitoneal paraganglioma presented as abdominal mass with symptoms of headache, palpitation and sweating.

\section{Case Presentation}

A 35-year-old male, farmer by occupation was admitted in surgical ward for abdominal mass. The patient was apparently alright four months back when he started complaining of intermittent headache, palpitations and sweating which relieved on its own. There was no history of chest pain, weight loss, weight gain, haematuria, breathlessness, lower limb oedema or facial puffiness. On further enquiry, the patient also complained of visual blackouts after sudden getting up from bed.

The patient was started on telmisartan $40 \mathrm{mg}$ once daily for the treatment of hypertension since four months. He had no tuberculosis, diabetes mellitus, asthma or any major

Financial or Other, Competing Interest: None.

Submission 18-05-2016, Peer Review 22-07-2016,

Acceptance 28-07-2016, Published 08-08-2016.

Corresponding Author:

Dr. Vinayak Sawardekar,

\#A5, Rameshwar Soc.,

Near Thane Municipal Corporation,

Panchpakhadi, Thane (w)-400602.

E-mail: vinayaks1812@gmail.com

DOI: $10.14260 /$ jemds/2016/1025 medical or surgical illness in the past. There was no similar illness in any family members. There was no addiction of alcohol, smoking or any other substance.

On general examination, the patient was afebrile with pulse rate of $102 / \mathrm{min}$. Blood pressure in right arm in supine and standing position was 148/110 $\mathrm{mmHg}$ and $118 / 80 \mathrm{mmHg}$ respectively. Respiratory rate was $18 / \mathrm{min}$. There was no pallor, icterus, clubbing, cyanosis, lymphadenopathy, raised jugular venous pressure or any evidence of skin hyper- or hypo-pigmentation or skin lesions. His BMI was $27.45 \mathrm{~kg} / \mathrm{m} 2$. Cardiovascular system, respiratory system and per abdomen examination was normal. The patient was conscious and oriented without signs of any focal neurological deficit. The investigation report is given in Table 1.

\begin{tabular}{|c|c|}
\hline Investigation & Result \\
\hline $\mathrm{Hb}$ & $13.4 \mathrm{~g} / \mathrm{dL}$ \\
\hline Platelet & $162,000 / \mathrm{cmm}$ \\
\hline White Blood Cells (WBC) & $7100 / \mathrm{cmm}$ \\
\hline Total Bilirubin & $0.8 \mathrm{mg} \%$ \\
\hline SGOT & $47 \mathrm{U} / \mathrm{L}$ \\
\hline SGPT & $42 \mathrm{U} / \mathrm{L}$ \\
\hline Total Proteins & $6.6 \mathrm{~g} / \mathrm{dL}$ \\
\hline Albumin & $4.2 \mathrm{~g} / \mathrm{dL}$ \\
\hline Globulin & $2.4 \mathrm{~g} / \mathrm{dL}$ \\
\hline Creatinine & $0.9 \mathrm{mg} / \mathrm{dL}$ \\
\hline Urea & $21 \mathrm{mg} / \mathrm{dL}$ \\
\hline Uric Acid & $4.4 \mathrm{mg} / \mathrm{dL}$ \\
\hline Serum Calcium & $9.4 \mathrm{mg} \%$ \\
\hline Serum Phosphorus & $4 \mathrm{mg} \%$ \\
\hline Serum Sodium & $139 \mathrm{mg} \%$ \\
\hline Serum Potassium & $3.7 \mathrm{mg} \%$ \\
\hline Serum Cholesterol & $44 \mathrm{mg} / \mathrm{dL}$ \\
\hline HDL Cholesterol & $38 \mathrm{mg} / \mathrm{dL}$ \\
\hline VLDL Cholesterol & $24 \mathrm{mg} / \mathrm{dL}$ \\
\hline Triglyceride & $89 \mathrm{mg} / \mathrm{dL}$ \\
\hline Fasting Blood Glucose & $78 \mathrm{mg} / \mathrm{dL}$ \\
\hline Postprandial Blood Glucose & $108 \mathrm{mg} / \mathrm{dL}$ \\
\hline $\mathrm{T} 3$ & $1.6 \mathrm{ng} / \mathrm{dL}$ \\
\hline $\mathrm{T} 4$ & $7.45 \mathrm{mg} / \mathrm{dL}$ \\
\hline TSH & $0.75 \mathrm{uIU} / \mathrm{mL}$ \\
\hline \multicolumn{2}{|c|}{ Table 1: Investigations } \\
\hline
\end{tabular}


Nothing abnormal was detected on chest X-ray and ECG. Patient underwent abdomen and pelvis ultrasound on 7/6/14 in a private hospital for complaint of constipation. The ultrasound showed evidence of moderate sized fairly welldefined lobulated retroperitoneal mass on left side in umbilical region located anterior to left kidney, pancreatic body located on anterior aspect. The mass was approximately $53 \mathrm{~mm}$ in maximum dimension and seen to indented and narrowed left renal vein (Figure 1).
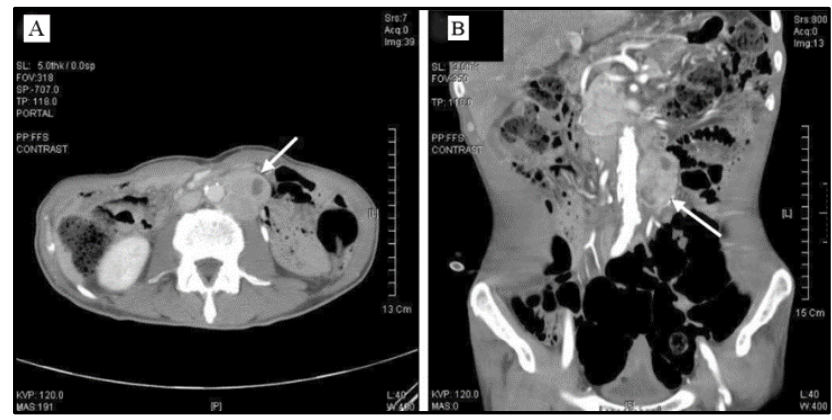

Fig. 1: Retroperitoneal Paraganglioma

Ultrasound-guided Fine Needle Aspiration Cytology (FNAC) of retroperitoneal mass performed in surgical ward revealed well encapsulated tumour in nested pattern and separated by fibrous septa imparting a Zellaballen arrangement. The individual tumour cells were polygonal with moderate amount of eosinophilic cytoplasm with ill-defined cytoplasmic borders. The nuclei were round to oval showing mild pleomorphism and hyperchromasia. Few cells showed intranuclear inclusions and a few intracytoplasmic hyaline globules and coarse brown black pigment in the sections studied. Mitotic activity was minimal. There was no evidence of necrosis, cystic change or vascular invasion. The ultrasound impression was retroperitoneal paraganglioma. The patient was then referred to Medicine Department in view of high blood pressure and fitness for surgery.

Patient transferred to medicine ward on 24th July 2015 for further investigations and preoperative preparation. Patient was planned for 24-hour urinary and plasma fractionated metanephrines, normetanephrines and catecholamines and I123 Metaiodobenzylguanidine (MIBG) scan. However, due to financial problems, patient was not ready for further investigations. The 24-hour metanephrine in urine was 15.48 $\mathrm{ng} / \mathrm{mL}$ with 24-hour urine volume of $3800 \mathrm{~mL}$. The fractionated metanephrine in the urine was $58.82 \mathrm{ug} /$ day (Normal 0-350 ug/day). Plasma free nor-metanephrine and plasma free metanephrine were $1,912 \mathrm{pg} / \mathrm{mL}$ (Normal 0.00$180 \mathrm{pg} / \mathrm{mL}$ ) and $12.10 \mathrm{pg} / \mathrm{mL}$ (Normal 0.00-90.00) respectively.

In view of FNAC report, raised plasma nor-metanephrine levels and diagnosis of paraganglioma. previous antihypertensive medications were stopped and the patient was started on oral phenoxybenzamine $10 \mathrm{mg}$ twice daily, which was gradually titrated to $10 \mathrm{mg}$ thrice daily, $20 \mathrm{mg}$ thrice daily then to $20 \mathrm{mg}$ four times daily to attain target blood pressure of $120 / 80 \mathrm{mmHg}$ in supine position.

Circulating catecholamines and complete alphaadrenergic blockade lead to tachycardia for the treatment of which the patient was started on oral propranolol $10 \mathrm{mg}$ twice daily four days prior to surgery. The dose of propranolol was gradually titrated to $10 \mathrm{mg}$ three times daily and then to four times daily to attain target heart rate of $60-80 / \mathrm{min}$. The blood pressure and heart rate readings are given in Table 2 .

\begin{tabular}{|c|c|c|c|}
\hline Date & $\begin{array}{l}\text { Supine Blood } \\
\text { Pressure }\end{array}$ & $\begin{array}{c}\text { Standing Blood } \\
\text { Pressure }\end{array}$ & $\begin{array}{l}\text { Heart } \\
\text { Rate }\end{array}$ \\
\hline \multirow{3}{*}{$2 / 8 / 2014$} & $\begin{array}{c}8 \mathrm{AM} \mathrm{160/90} \\
\mathrm{mmHg}\end{array}$ & $\begin{array}{l}8 \mathrm{AM} 120 / \\
80 \mathrm{mmHg}\end{array}$ & \multirow{3}{*}{$102 / \mathrm{min}$} \\
\hline & $\begin{array}{c}3 \text { PM 170/100 } \\
\text { mmHg }\end{array}$ & $\begin{array}{c}3 \mathrm{PM} \mathrm{110/80} \\
\mathrm{mmHg}\end{array}$ & \\
\hline & $\begin{array}{c}8 \text { PM 168/102 } \\
\text { mmHg }\end{array}$ & $\begin{array}{c}8 \text { PM 108/70 } \\
\text { mmHg }\end{array}$ & \\
\hline \multirow{3}{*}{$12 / 8 / 2014$} & $\begin{array}{c}8 \mathrm{AM} \mathrm{160/100} \\
\mathrm{mmHg}\end{array}$ & $\begin{array}{c}8 \mathrm{AM} 100 / 70 \\
\mathrm{mmHg}\end{array}$ & \multirow{3}{*}{$120 / \mathrm{min}$} \\
\hline & $\begin{array}{c}3 \mathrm{PM} \mathrm{150/90} \\
\mathrm{mmHg}\end{array}$ & $\begin{array}{c}3 \mathrm{PM} \mathrm{100/60} \\
\text { mmHg }\end{array}$ & \\
\hline & $\begin{array}{c}8 \text { PM 148/80 } \\
\text { mmHg }\end{array}$ & $\begin{array}{c}8 \mathrm{PM} 110 / 80 \\
\mathrm{mmHg}\end{array}$ & \\
\hline \multirow{3}{*}{$18 / 8 / 2014$} & $\begin{array}{c}8 \mathrm{AM} 140 / 90 \\
\mathrm{mmHg}\end{array}$ & $\begin{array}{c}8 \mathrm{AM} 100 / 70 \\
\mathrm{mmHg}\end{array}$ & \multirow{3}{*}{$90 / \mathrm{min}$} \\
\hline & $\begin{array}{c}3 \mathrm{PM} 140 / 80 \\
\mathrm{mmHg}\end{array}$ & $\begin{array}{c}3 \mathrm{PM} 110 / 80 \\
\mathrm{mmHg}\end{array}$ & \\
\hline & $\begin{array}{c}8 \mathrm{PM} \mathrm{130/90} \\
\mathrm{mmHg}\end{array}$ & $\begin{array}{c}8 \mathrm{PM} 112 / 70 \\
\mathrm{mmHg}\end{array}$ & \\
\hline
\end{tabular}

Endocrinologist was consulted for expert opinion who advised combined $\alpha$ - and $\beta$-adrenergic blockade to control blood pressure and prevent intraoperative hypertensive crises.

\section{DISCUSSION}

About $10-15 \%$ of paragangliomas are extra-adrenal in nature. ${ }^{4}$ Retroperitoneal paragangliomas originate from neural crest cells present along the aorta and sympathetic chain, i.e. parganglia. 5,6

The patient with functional paraganglioma may have symptoms of hypertension, headache, sweating and abdominal mass. ${ }^{4}$ Our patient had history of intermittent headache, palpitations and sweating. Though there was an abdominal mass, patient did not have any pain in abdomen. Heritability is common in paragangliomas. ${ }^{7}$ However, in this case, there was no family history of similar complaints. Catecholamine-secreting paragangliomas can be located by 131 iodine- or 123-iodine-MIBG scintigraphy, a safer option than angiography. ${ }^{8}$ We did not perform MIBG scintigraphy because of financial constraints of the patient.

Phenoxybenzamine, a non-competitive, irreversible alphaadrenergic blocker is commonly used agent in pre-operative settings. ${ }^{8}$ We started the patient on phenoxybenzamine and propranolol. With these drugs, the blood pressure and symptoms of patients were relatively well controlled. Patients should be advised to take high sodium diet after starting alpha blockage as catecholamine can cause volume contraction and $\alpha$-adrenergic blockade may be associated with orthostasis. ${ }^{9}$ Surgical removal is the only curative treatment option for extra-adrenal paragangliomas. ${ }^{10}$ The functional and symptomatic tumours can be removed by careful surgery. Intravenous hypertensives such as sodium nitroprusside, phentolamine or nicardipine are required for the treatment of acute hypertensive crisis, which can occur prior or during the operative procedure.11 Esmolol and lidocaine injection are useful for the management of intraoperative arrhythmia. 
Hypotension can be another complication during or postsurgery for which fluids and colloids and sometimes intravenous pressor agents may be required. After surgery, 24-hour urine examination is done for measuring fractionated catecholamines and metanephrines levels. ${ }^{12}$ We referred the patient back to Surgery Department for removal of retroperitoneal paraganglioma.

\section{CONCLUSION}

We report a case of functional retroperitoneal paraganglioma, an extra-adrenal tumours of the autonomic nervous system diagnosed with histological examination. Phenoxybenzamine and propranolol are useful drugs for medical management of functional retroperitoneal paraganglioma; however, surgical removal is the treatment of choice for such cases.

\section{REFERENCES}

1. Fishbein L, Orlowski R, Cohen D. Pheochromocytoma /paraganglioma: review of perioperative management of blood pressure and update on genetic mutations associated with pheochromocytoma. J Clin Hypertens (Greenwich) 2013;15(6):428-34.

2. Sangster G, Do D, Previgliano C, et al. Primary retroperitoneal paraganglioma simulating a pancreatic mass: a case report and review of the literature. HPB Surgery, Article ID 645728 2010;2010:4. doi:10.1155/2010/645728.

3. Arrabal-Polo MA, Arrabal-Martin M, Lopez-Leon VM, et al. Spontaneous retroperitoneal abscess as the first clinical manifestation of a non-functioning retroperitoneal paraganglioma. Ann R Coll Surg Engl 2010;92(3):W17-9.
4. Brahmbhatt P, Patel P, Saleem A, et al. Retroperitoneal paraganglioma presenting as a chest pain: a case report. Case Reports in Oncological Medicine, Article ID 329472 2013;2013:4. http://dx.doi.org/10.1155/2013/329472.

5. Hayes WS, Davidson AJ, Grimley PM, et al. Extra-adrenal retroperitoneal paraganglioma: clinical, pathologic, and CT findings. American Journal of Roentgenology 1990; 155(6):1247-50.

6. Limaiem F, Bouraoui S, Bouslama S, et al. Retroperitoneal non-functioning paraganglioma: a case report. J Interdiscipl Histopathol 2013;1(3):168-71.

7. Dahia PL. Pheochromocytoma and paraganglioma pathogenesis: learning from genetic heterogeneity. Nature Reviews Cancer 2014;14(2):108-19.

8. Colen TY, Mihm FG, Mason TP, et al. Catecholaminesecreting paragangliomas: recent progress in diagnosis and perioperative management. Skull Base 2009; 19(6):377-85.

9. Cecil RLF, Goldman L, Schafer AI. Goldman's Cecil Medicine. 24th ed. Vol. 1. Elsevier 2012.

10. Ahmad S, Cathy D, Sheikh M, et al. Retroperitoneal extra-adrenal paraganglioma: a rare but important diagnosis. Irish Journal of Medical Science 2009; 178(2):211-4

11. Melmed S, Polonsky KS, Larsen PR, et al. Williams Textbook of Endocrinology. 13 th ed. Elsevier 2016.

12. Gopal RA. Pheochromocytoma. BMH Medical Journal 2014;1(3):47-51. 